\title{
THE NATURAL REGENERATION OF SPRUCE IN CENTRAL BRITISH COLUMBIA
}

\author{
B. G. GRIFFITH \\ Research Division, British Columbia Forest Service
}

\section{INTRODUCTION}

T has been observed for a long time that the understory of the sprucebalsam forest type is composed largely of balsam, even where spruce is the dominant species in the cover stand. The writer, under the direction of Dr. P. M. Barr, undertook to investigate the cause of this poor restocking of spruce in the spruce-balsam type of Central British Columbia, and to find out what conditions favored the germination and survival of this species. The work was commenced in the early summer of 1926, and was centralized at the Aleza Lake Forest Experiment Station.

The investigations embodied in this report are in the nature of a survey of present conditions in mature stands of spruce and balsam, combined with a study of the seed-bed conditions favorable to spruce germination and survival. The general investigation included three separate studies:-

1. The securing of information as to the compasition of the mature forest, and the proportions of species in its understory.

2. A study of the ground cover in the forest, with identification of its herbaceous and shrubby flora.

3. An investigation of seed bed conditions and the effect of root competition on the germination and survival of spruce seedlings under natural conditions of forest cover.

\section{FIELD WORK}

Twelve sample plots were established at the Forest Experiment Station in 1926, on carefully selected sites, so as to obtain a fairly even distribution of plots on northern and southern exposures, good and poor sites, and on areas which apparently contained high and low percentages of spruce regeneration as compared with the balsam. Six of the plots were located on northern and six on southern exposures.

Each plot was two chains square, (four-tenths of an acre in area), and divided into quarters. To facilitate counting the regeneration and tallying the larger trees, each quarter was further subdivided into twenty-five equal parts, twenty links square. When counting the trees on the area the boundaries of these twenty-five sections were marked off with cord, which was later removed. On each plot all trees four inches and over in D.B.H. were numbered and tallied by species; D.B.H. to the nearest tenth of an inch; and total height to the nearest foot. The position of each tree was also 
charted on a map of the plot. Trees under four inches D.B.H. were tallied by species and height, in two foot height classes.

For a more detailed study of the ground cover and seed bed conditions, a quadrat was laid out on each quarter-plot, and each series of four quadrats was treated as follows:-

No. 1. Quadrat left untreated as a control area.

No. 2. A narrow trench was dug around the quadrat, cutting off all the tree roots entering the enclosed area. This trench was about twelve inches wide, and deep enough to be below all the roots; a depth of eighteen inches usually was sufficient. After severing all the roots the trench was filled in again to prevent artificial drainage of the quadrat. Any trees within the quadrat were cut and removed. The ground surface was disturbed as little as possible during the digging of the trench and the removal of the trees.

No. 3. On this quadrat the surface layers of moss, litter and humus were scraped off, so as to expose the mineral soil, and any trees growing on the area were left standing.

No. 4. This quadrat was trenched similarly to Number 2 above, and the trees were cut and removed; the mineral soil, however, was exposed as in quadrat Number 3.

The arrangement of a typical plot, Number 9, is shown in Fig. 1. All the trenched quadrats were retrenched in the spring of 1929 , to cut off any roots which had penetrated the area since the trenching of 1926.

The amount of light on each quadrat was estimated relatively by considering the height and size of the openings in the crown cover as an index of the light intensity on the forest floor. The amount of light on the quad. rats was recorded in four classes, "X," where the ground was moderately shaded by mature trees, "XX," dense shade cast by mature trees, "O," moderate shade cast by young reproduction ( $4.15 \mathrm{ft}$. in height), and "OO," fairly dense shade cast by young reproduction. The slope of each quadrat was deter. mined by means of an Abney level.

The four quadrats on each of the twelve plots were examined for seed germination and survival three times during the summers of 1927, 1928, and 1929. The first examination was made in June of each year, the second about the middle of the summer, and the final inspection near the last of September or early in October. On each occasion the quadrats were searched for seed germination which was recorded according to species, and the position of each seedling was charted. The seedlings were numbered on the quadrats by means of wooden pot-labels; as the seedlings died these markers were pulled up. The date of each death was recorded and the cause noted when it could be ascertained. The ground cover on the quadrats was also identified, and an estimate made of the proportion of the total area covered by herbaceous and woody vegetation. To facilitate tallying and charting the 


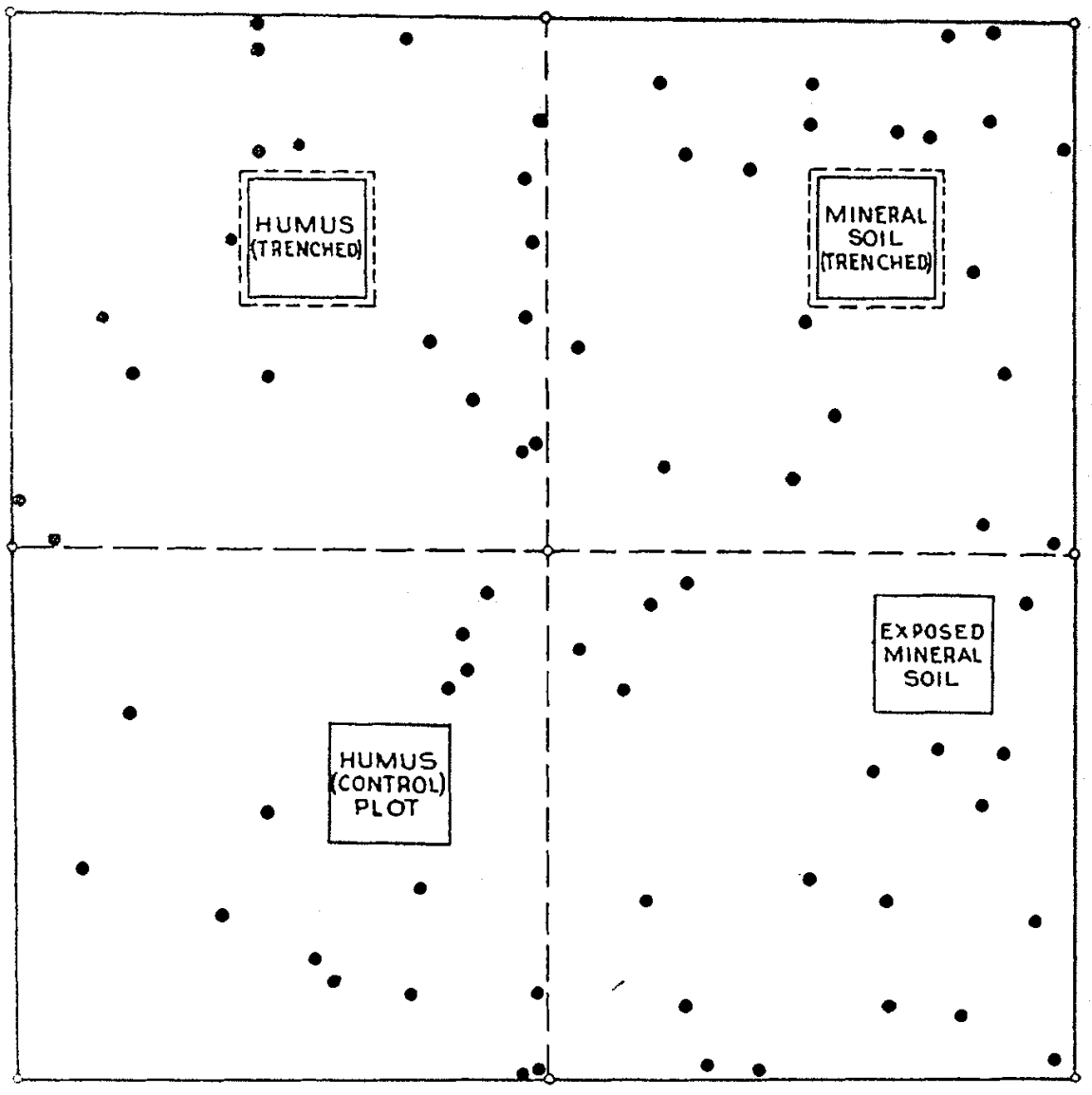

Fig 1 - Chart of Typical Experimental Plot (No.9)

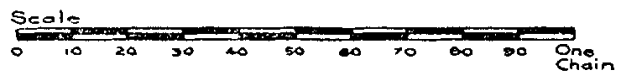

Trees over 4.0" D.B.H. shown by $\bullet$

germinants and estimating the percentage of ground cover the quadrats were divided by strings into three equal parts. In the case of the control quadrats and those on which the humus had been trenched it was found to be impracticable to search thoroughly the whole area for seedlings on account of the dense covering of moss and other vegetation, and in practice five strips, each one foot in width, were run across the quadrats, at regular intervals, and parallel to the prevailing slope. These strips were carefully examined and all seedlings were tallied and charted. 


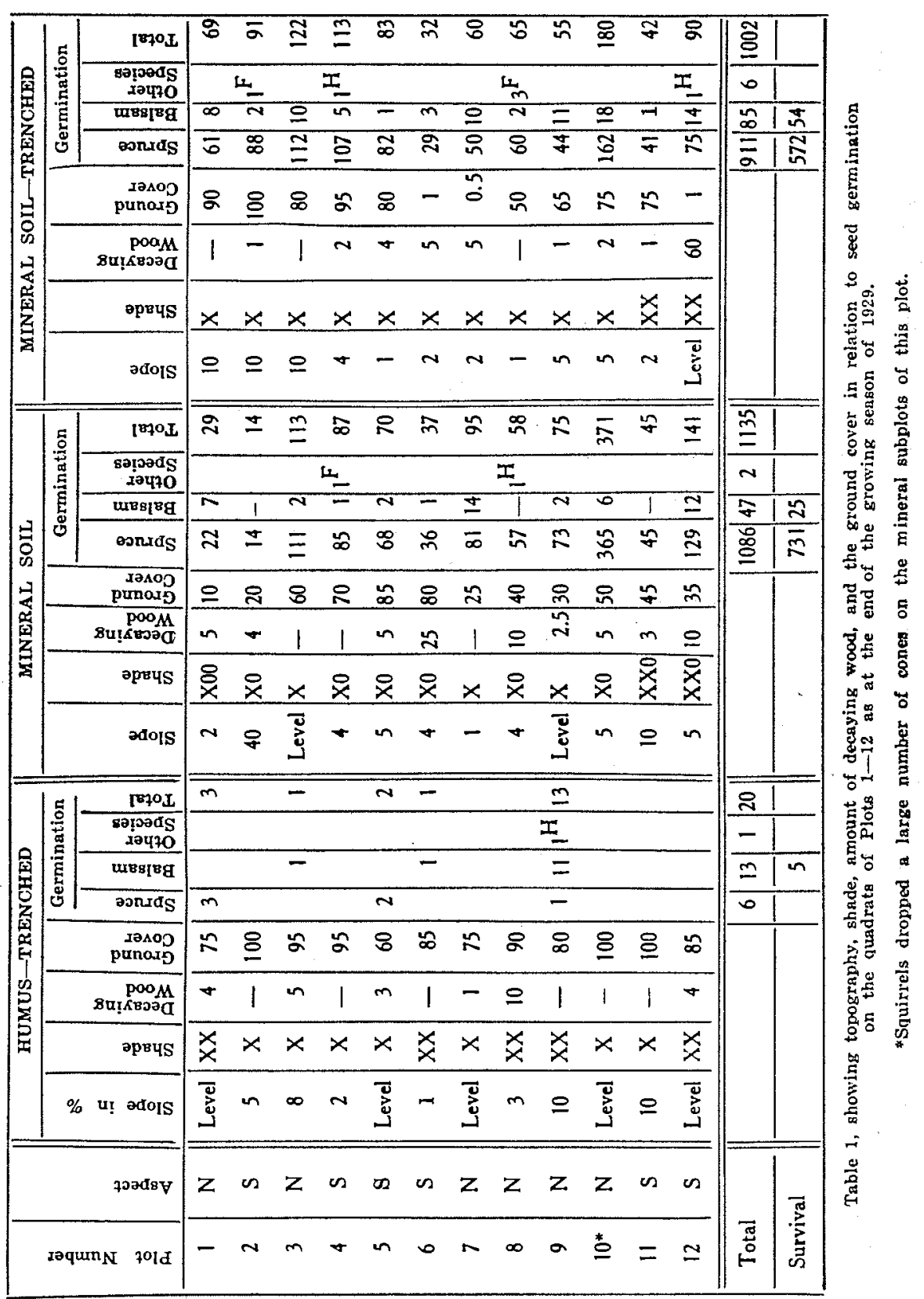




\begin{tabular}{|c|c|c|c|c|c|c|}
\hline \multicolumn{7}{|c|}{$\begin{array}{c}\text { TABLE } 2 \\
\text { Stand per Acre on the Experimental Plots } \\
\text { (Trees over } 4.0^{\prime \prime} \text { D.B.H.) }\end{array}$} \\
\hline \multirow{2}{*}{$\begin{array}{l}\text { D.B.H. } \\
\text { Classes }\end{array}$} & Spruce & Balsam & Birch & Hemlock & D. Fir & Aspen \\
\hline & \multicolumn{6}{|c|}{ Number of Trees per Acre } \\
\hline $4^{\prime \prime}-8^{\prime \prime}$ & 26.5 & 37.4 & & & & \\
\hline $8^{\prime \prime}-12^{\prime \prime}$ & 19.4 & 48.6 & & & & \\
\hline $12^{\prime \prime}-16^{\prime \prime}$ & 28.7 & 22.7 & & & & \\
\hline Over 16" & 22.6 & 3.8 & & & & \\
\hline Total & 97.2 & 112.5 & 11.7 & 2.9 & 1.7 & 0.4 \\
\hline \multicolumn{7}{|c|}{ Total-226 trees per acre } \\
\hline
\end{tabular}




\begin{tabular}{|c|c|c|c|c|}
\hline \multicolumn{5}{|c|}{ TABLE 3 } \\
\hline \multirow{5}{*}{$\begin{array}{c}\text { Plot } \\
\text { No. }\end{array}$} & Spruce & Balsam & $\begin{array}{c}\text { Other } \\
\text { Species }\end{array}$ & Total \\
\cline { 2 - 5 } & \multicolumn{3}{|c|}{ Basal Area, in Square Feet } \\
\hline 1 & 49.6 & 19.2 & 6.2 & 75.0 \\
2 & 34.5 & 13.8 & 2.2 & 50.5 \\
3 & 31.9 & 22.3 & 6.4 & 60.6 \\
4 & 40.7 & 27.4 & 5.3 & 73.4 \\
5 & 35.2 & 21.5 & 4.8 & 61.5 \\
6 & 57.1 & 16.3 & 4.5 & 77.9 \\
7 & 28.2 & 35.2 & 2.6 & 66.0 \\
8 & 37.4 & 23.0 & 2.0 & 62.4 \\
9 & 35.5 & 30.2 & 3.0 & 68.7 \\
10 & 32.6 & 19.3 & 6.8 & 58.7 \\
11 & 48.5 & 27.1 & 2.8 & 78.4 \\
12 & 25.1 & 40.0 & 6.1 & 71.2 \\
\hline Total & 456.3 & 295.3 & 52.7 & 804.3 \\
\hline Average & 95.1 & 61.5 & 11.0 & 167.6 \\
\hline per Acre & & & & \\
\hline & & & & \\
\hline
\end{tabular}




\begin{tabular}{|c|c|c|c|c|c|c|c|c|c|c|}
\hline \multicolumn{11}{|c|}{ TABLE 4-Trees Under 4.0" D.B.H. } \\
\hline \multirow{3}{*}{$\begin{array}{l}\text { Plot } \\
\text { No. }\end{array}$} & \multirow{3}{*}{ Aspect } & \multicolumn{4}{|c|}{ SPRUCE } & \multicolumn{4}{|c|}{ BALSAM } & \multirow{3}{*}{$\begin{array}{l}\text { Total } \\
\text { Trees } \\
\text { on } \\
\text { Plot }\end{array}$} \\
\hline & & \multicolumn{3}{|c|}{ Trees Per Plot } & \multirow{2}{*}{$\begin{array}{c}\% \text { of } \\
\text { Both } \\
\text { Species }\end{array}$} & \multicolumn{3}{|c|}{ Trees Per Plot } & \multirow{2}{*}{$\begin{array}{c}\% \text { of } \\
\text { Both } \\
\text { Species }\end{array}$} & \\
\hline & & $\begin{array}{c}\text { Under } \\
4^{\prime} \text { High }\end{array}$ & 4' ${ }^{\text {Over }}$ High & Total & & $\begin{array}{l}\text { Under } \\
4^{\prime} \text { High }\end{array}$ & $\begin{array}{r}\text { Over } \\
4^{\prime} \text { High }\end{array}$ & Total & & \\
\hline 1 & $\mathbf{N}$ & 127 & 123 & 250 & 12.8 & 1113 & 586 & 1699 & 87.2 & 1949 \\
\hline 2 & S & 159 & 63 & 222 & 13.9 & 1084 & 292 & 1376 & 86.1 & 1598 \\
\hline 3 & $\mathbf{N}$ & 84 & 178 & 262 & 20.5 & 614 & 432 & 1046 & 79.5 & 1308 \\
\hline 4 & $\mathrm{~s}$ & 211 & 392 & 603 & 30.9 & 932 & 414 & 1346 & 69.1 & 1949 \\
\hline 5 & $\mathrm{~s}$ & 44 & 101 & 145 & 9.8 & 543 & 791 & 1334 & 90.2 & 1479 \\
\hline 6 & $\mathrm{~s}$ & 63 & 123 & 186 & 13.0 & 673 & 568 & 1241 & 87.0 & 1427 \\
\hline 7 & $\mathrm{~N}$ & 86 & 327 & 413 & 25.0 & 778 & 463 & 1241 & 75.0 & 1654 \\
\hline 8 & $\mathbf{N}$ & 58 & 155 & 213 & 12.0 & 1110 & 448 & 1558 & 88.0 & 1771 \\
\hline 9 & $\mathrm{~N}$ & 89 & 452 & 541 & 29.9 & 733 & 536 & 1269 & 70.1 & 1810 \\
\hline 10 & $\mathbf{N}$ & 59 & 260 & 319 & 18.7 & 542 & 848 & 1390 & 81.3 & 1709 \\
\hline 11 & $s$ & 83 & 93 & 176 & 9.8 & 1043 & 578 & 1621 & 90.2 & 1797 \\
\hline 12 & $s$ & 3 & 259 & 262 & 21.8 & 416 & 526 & 942 & 78.2 & 1204 \\
\hline \multicolumn{2}{|c|}{ Total } & $\overline{1066}$ & 2526 & 3592 & - & 9581 & 6482 & 1.6063 & - & 19655 \\
\hline \multicolumn{2}{|c|}{ Average per } & 222 & 526 & 748 & 18.3 & 1996 & 1350 & 3346 & 81.7 & 4094 \\
\hline
\end{tabular}


A general summary of all the plots is given in Table 1, with details of ground cover, shade conditions, and germination.

Near the end of the growing season of 1928 , in order to obtain a closer estimate of the herbaceous growth on the different quadrats, all the vegetation, with the exception of the moss, was stripped off a representative area one metre square, in each quadrat. These samples were then thoroughly dried in an oven and weighed. The results are shown in Table 9.

\section{RESULTS}

In the mature spruce-balsam forest of the Aleza Lake Experiment Station the total number of balsams over 4 in. D.B.H. slightly exceeds the number of spruce (Table 2), the latter composing 46 per cent of the stand and including most of the dominant trees, with a much greater basal area than that of balsam. The total basal area of the spruce on the twelve sample plots is 456.3 square feet, and that of balsam only 295.3 square feet, while other species amount to 52.7 square feet (Table 3). In the understory (trees under 4.0 inches D.B.H.) the proportion of spruce is very unsatisfactory, comprising only 18.3 per cent of the total reproduction. On the northern slopes the percentage of spruce is a little higher. (Table 4).

\begin{tabular}{|c|c|c|c|c|c|c|c|c|c|c|}
\hline & & Reprod & action & on Plo & $\begin{array}{l}\text { ABLE } 5 \\
\text { No. } 4-\end{array}$ & Sorth & rest 6 & uarte & & \\
\hline & & & PRU & & & & & BALS & & \\
\hline $\begin{array}{l}\text { Height } \\
\text { in }\end{array}$ & & $\begin{array}{l}\text { eaying } \\
\text { Wood }\end{array}$ & Min & & & & Joayin & Min & & \\
\hline & No. & $\%$ & No. & $\%$ & Reprod. & No. & $\%$ & No. & $\%$ & Reprod. \\
\hline $0-2$ & 14 & 73.7 & 5 & 26.3 & 19 & 45 & 38.8 & 71 & 61.2 & 116 \\
\hline $2-4$ & 30 & 75. & 10 & 25. & 40 & 38 & 57.6 & 28 & 42.4 & 66 \\
\hline $4-6$ & 49 & 96.1 & 2 & 3.9 & 51 & 20 & 62.5 & 12 & 37.5 & 32 \\
\hline $6-8$ & 42 & 89.3 & 5 & 10.7 & 47 & 5 & 27.8 & 13 & 72.2 & 18 \\
\hline $8-10$ & 20 & 100. & - & - & 20 & 8 & 80.0 & 2 & 20.0 & 10 \\
\hline $.10-12$ & 15 & 79.0 & 4 & 21.0 & 19 & 3 & 42.9 & 4 & 57.1 & 7 \\
\hline 12 & 14 & 77.8 & 4 & 22.2 & 18 & 1 & 50.0 & 1 & 50.0 & 2 \\
\hline Total & 184 & 85.9 & 30 & 14.1 & 214 & 120 & 47.9 & 131 & 52.1 & 251 \\
\hline
\end{tabular}




\begin{tabular}{|c|c|c|c|c|}
\hline Sumn & $\begin{array}{l}\text { TABLE } \\
\text { of Abundan } \\
\text { Various Soil }\end{array}$ & $\begin{array}{l}6 \\
\text { Surfaces }\end{array}$ & tion & \\
\hline SPECIES & $\begin{array}{c}\text { Humus } \\
\text { Soil } \\
\text { Before } \\
\text { Trenching } \\
\text { (1926) }\end{array}$ & $\begin{array}{l}\text { Humus } \\
\text { Soil } \\
\text { After } \\
\text { Trenching } \\
\text { (1927) }\end{array}$ & $\begin{array}{c}\text { Mineral } \\
\text { Soil } \\
\text { Trenched } \\
\text { (1927) }\end{array}$ & $\begin{array}{l}\text { Mineral } \\
\text { Soil } \\
\text { Un- } \\
\text { trenched } \\
\text { (1927) }\end{array}$ \\
\hline & $\begin{array}{r}\text { Order of } \\
\text { based }\end{array}$ & $\begin{array}{l}\text { bundance } \\
\text { on tallies }\end{array}$ & $\begin{array}{l}\text { ten princ } \\
\text { rom all } 12\end{array}$ & $\begin{array}{l}\text { al species, } \\
\text { oints }\end{array}$ \\
\hline Cornus canadensis & 1 & 5 & 8 & 6 \\
\hline Rubus pedatus & 2 & 1 & 9 & 5 \\
\hline Tiarella unifoliata & 3 & 3 & 5 & 1 \\
\hline Clintonia uniflora & 4 & 8 & 一 & 7 \\
\hline Lonicera involucratum & 5 & - & - & - \\
\hline Streptopus roseus & 6 & 4 & 6 & 2 \\
\hline Phegopteris Dryopteris & 7 & 6 & - & 一 \\
\hline Viburnum pauciflorum & 8 & 一 & - & - \\
\hline Aralia nudicaulis & 9 & 10 & 3 & 9 \\
\hline Rosa nutkana & 10 & 一 & - & 10 \\
\hline Petastites speciosa & - & 2 & 2 & 3 \\
\hline Rubus parviflorus & - & 7 & 7 & 4 \\
\hline Spiraea spp. & 一 & 9 & 1 & 8 \\
\hline Aster Englemannii & - & - & 4 & 一 \\
\hline Disporum spp. & - & - & 10 & - \\
\hline
\end{tabular}

When selecting sites for the twelve plots it was noticed that spruce reproduction was much more abundant on old decaying Douglas fir logs than elsewhere, often occurring in straight rows in the forest where no logs were evident from the surface. To find out how much of the reproduction actually did originate on decaying wood, the reproduction on the northwest quarter of Plot 4 was classified as to whether it was growing in a layer of decaying wood or on the mineral soil beneath the surface horizons of moss and humus. As shown in Table 5, it was found that 86 per cent of the spruce was grow- 


\begin{tabular}{|c|c|c|c|c|}
\hline \multicolumn{5}{|c|}{$\begin{array}{c}\text { TABLE } 7 \\
\text { Seedling Germination and Mortality } \\
\text { (Averages from } 12 \text { Plots, 1927-28-29) }\end{array}$} \\
\hline & $\begin{array}{c}\text { Control } \\
\text { Area }\end{array}$ & $\begin{array}{l}\text { Humus, } \\
\text { Trenched }\end{array}$ & $\begin{array}{c}\text { Mineral } \\
\text { Soil }\end{array}$ & $\begin{array}{l}\text { Mineral } \\
\text { Soil } \\
\text { Trenched }\end{array}$ \\
\hline & \multicolumn{4}{|c|}{ Number of Seedlings per Acre } \\
\hline 1927 & & 100 & 3700 & 3745 \\
\hline 1928 & & - & 9180 & 9655 \\
\hline 1929 & & - & 236 & 145 \\
\hline Total & Nil & 100 & 13116 & 13545 \\
\hline 1927 & & 33 & 582 & 254 \\
\hline 1928 & & 17 & 1708 & 1491 \\
\hline 1929 & & 50 & 2460 & 3309 \\
\hline Total & - & 100 & 4750 & 5054 \\
\hline $\begin{array}{c}\text { Survival } \\
\text { October } \\
1929\end{array}$ & Nil & Nil & 8366 & 8491 \\
\hline
\end{tabular}

ing on a substratum of decaying wood, while only 48 per cent of the balsam occurred on a similar stratum.

The forest floor was covered by a varying thickness of moss composed of the genera Hypnum, Mnium, Hylocomium, and Rhytidiadelphus. The herbaceous flora occurring on the twelve plots is listed in Table 6 in the order of abundance of the species.

\section{EFFECT OF EXPOSURE ON MINERAL SOIL}

Exposing the mineral soil by scraping off the surface layers of moss, litter and humus greatly increased the establishment of spruce seedlings, (Table 7). During the three years 1927, 1928 and 1929, over 13,000 spruce seed. lings per acre became established on the mineral soil quadrats. The years 1926, 1927 and 1928, however, were very poor seed years, few trees bearing cones, and after a good seed year probably a much greater number of seedings will result. It is known that with ordinary conditions the moss under spruce- 
balsam forests dries out very rapidly. Barr (1) has shown that generally there is insufficient moisture in the moss on the forest floor to make possible the germination of spruce seeds, such germinants as do occur often dying before the summer is over. Another reason for the poor survival of spruce seedlings in a heavy layer of moss is that the spruce root system is very shallow, penetrating very slightly through the surface layers, and then spreading out in a horizontal plane. There was little germination of balsam seeds even on the exposed mineral soil during the three years following the preparation of the plots. The only apparent cause of this condition was that during these years there occurred exceptionally poor crops of balsam seed.

Spruce germination was very poor on the quadrats of trenched humus, seedlings being found on only three of the twelve quadrats, with an average density of only 100 per acre.

In most instances there was much better germination in the second year

\begin{tabular}{|l|c|c|}
\hline \multicolumn{2}{|c|}{ TABLE 8 } \\
& \multicolumn{2}{|c|}{ Surface } \\
& Cause & Treatment \\
\cline { 2 - 3 } & $\begin{array}{c}\text { Mineral } \\
\text { Soil }\end{array}$ & $\begin{array}{c}\text { Mineral Soil } \\
\text { Trenched }\end{array}$ \\
\hline Animals ${ }^{\left({ }^{2}\right)}$ & $5.6 \%$ & $13.2 \%$ \\
Disease & 6.5 & 8.0 \\
Winter-killed ( $\left.{ }^{2}\right)$ & 31.0 & 30.6 \\
Shade & 1.7 & 2.6 \\
Mechanical Injury & 6.0 & 2.0 \\
Unknown & 49.2 & 43.6 \\
\hline
\end{tabular}

(i) Under mortality due to animals there have been included deaths of seedlings eaten by birds, animals, and rodents, and those trampled by larger animals.

(2) Seedlings which were healthy at the end of a growing season but were dead at the time of examination in the following spring have been described as winter-killed.

following the removal of the surface layers of vegetation and humus, than the first. The reason for this is not quite clear, but it may be on account of a slightly better seed crop in 1927 than in 1926. The third year after the

(1) Barr, P.M. The Effect of Soil Moisture on the Establishment of Spruce Reproduction. Bulletin 26. Yale School of Forestry, 1930. 
removal of the surface layers there was practically no germination, possibly due to the fact that by the end of three years the vegetation and moss had invaded the whole surface so that conditions were somewhat similar to what they had been originally. This was the case particularly in the trenched areas where the vegetation was much denser than it had been before trenching.

\begin{tabular}{|c|c|c|c|c|}
\hline \multirow{3}{*}{$\begin{array}{l}\text { Plot } \\
\text { No. }\end{array}$} & \multicolumn{4}{|c|}{$\begin{array}{r}\text { TABLE } 9 \\
\text { Relation of Soil-Type and Vegetation }\end{array}$} \\
\hline & Humus & $\begin{array}{l}\text { Humus } \\
\text { Trenched }\end{array}$ & $\begin{array}{l}\text { Mineral } \\
\text { Soil }\end{array}$ & $\begin{array}{c}\text { Mineral Soil } \\
\text { Trenched }\end{array}$ \\
\hline & \multicolumn{4}{|c|}{ Dry Weight of Vegetation, in grams } \\
\hline 1 & 17.6 & 187.7 & 4.2 & 104.4 \\
\hline 2 & 12.3 & 151.2 & 25.3 & 67.5 \\
\hline 3 & 77.0 & 150.5 & 23.4 & 128.3 \\
\hline 4 & 56.2 & 190.9 & 62.7 & 79.0 \\
\hline 5 & 52.2 & 104.0 & 10.9 & 90.3 \\
\hline 6 & 77.8 & 139.9 & 5.9 & 24.0 \\
\hline 7 & 20.6 & 151.5 & 16.5 & 47.1 \\
\hline 8 & 26.2 & 130.7 & 14.7 & 33.0 \\
\hline 9 & 40.5 & 134.7 & 17.7 & 67.7 \\
\hline 10 & 32.9 & 168.1 & 48.0 & 63.6 \\
\hline 11 & 8.0 & 102.3 & 41.6 & 96.3 \\
\hline 12 & 34.8 & 105.5 & 6.2 & 31.7 \\
\hline Total & 456.1 & 1717.0 & 277.1 & 832.9 \\
\hline Average & 38.0 & 143.1 & 23.1 & 69.4 \\
\hline
\end{tabular}

MORTALITY

Seedling deaths increased greatly during the third year after the treatment of the ground surface, due to the greater density of the vegetation, which killed many of the seedlings by shading, and through competition deprived the young seedlings of the available supplies of water and nutrients. (Table 7). It is thought that the chief factor was one of competition for the available moisture. As seedling mortality was practically the same on the trenched 


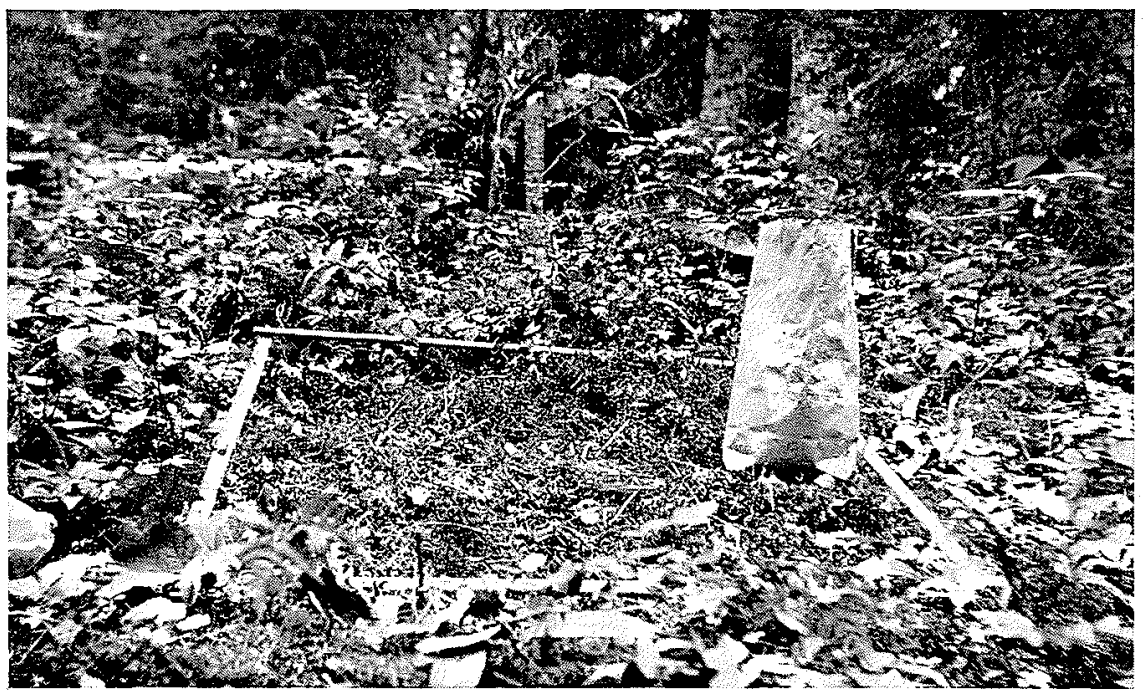

Fig. 2. Plot 4, control quadrat of undisturbed humus soil. Note the condition of the vegetation surrounding the small area, 1 meter square, on which the vegetation has been cut, and compare with Fig. 3.

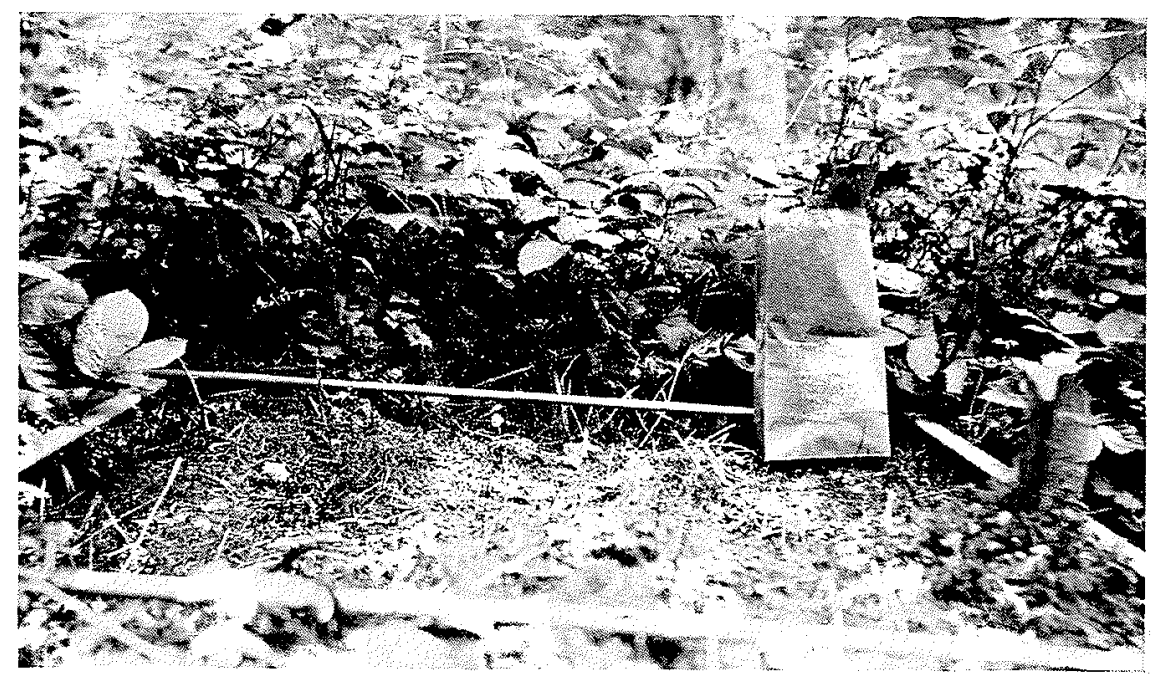

Fig. 3. Plot 4, trenched humus quadrat, showing the effect of trenching upon the vegetation. Note the dense, luxuriant growth of the vegetation as compared with the untrenched quadrat shown in Fig. 2. 
and on the untrenched quadrats, although the vegetation was three times as dense on the trenched quadrats, the explanation must be that no demand was made upon the trenched plots for nourishment by the surrounding trees, as on the untrenched ones. On the quadrats of mineral soil, 36.05 per cent of the spruce germinants had died by the end of the third year, on the quadrats of trenched mineral soil 35.95 per cent, and on the trenched-humus quadrats 100 per cent. If the amount of damage caused by animals is deducted from the total mortality then the number of deaths is 5.8 per cent less on northern than on southern exposures, for untrenched mineral soil, and 3.5 per cent less for trenched mineral soil.

The chief known cause of mortality was winter killing, as shown in Table 8.

\section{EFFECT OF TRENCHING}

Trenching an area has a much greater effect on the ground flora than on the seedlings. The trenched quadrats have had much denser and more luxuriant vegetation each year than that found on the untrenched quadrats, and this vegetation remained fresh and healthy much later in the fall. The appearance of the vegetation on typical quadrats on both undisturbed and trenched humus soil is shown in Figures 2 and 3.

In the natural forest a number of factors govern the nature of the understory, including light, soil moisture, heat, and available nutrients, and under certain conditions any one of these factors may become a limiting factor for the growth of seedlings. The effect of a limiting factor probably is the cause of inconsistencies in the germination on several of the plots.

In some instances there was much better regeneration of tree species on the trenched quadrats of mineral soil, but in other cases the untrenched soil gave better results. On Plot 2, for example, germination was much better on the trenched mineral soil than on the untrenched quadrat. This plot has an appreciable slope to the south, especially the quadrat of mineral soil where the slope is 40 per cent, so that the soil naturally would become warm and dry during the summer months. Here the soil moisture would be an important factor, and any system, such as trenching, which would increase the moisture supply would aid the growth of seedlings and vegetation. The ground cover became particularly dense on this quadrat, while there was practically none on the untrenched mineral soil. On Plot 1 the germination was poor on the mineral soil quadrat compared with that of the trenched quadrat; here the lack of seedlings on the mineral soil was due partly to soil moisture, but probably to a greater extent to the heavy shade caused by a dense stand of young trees ( 5.12 feet in height) on the area. The unfavourable seed bed conditions were aggravated by a considerable amount of litter, caused by the accumulation of fallen needles from many of the smaller trees which 
died as a result of the removal of the moss and humus layers. On Plot 6 there was better reproduction on the untrenched mineral soil than on the trenched. Due to an increased supply of available moisture on the trenched area a layer of moss spread over the quadrat during the summer following the removal of the moss and humus, and this made an unsatisfactory seed bed for spruce. On the mineral soil quadrat the seed bed conditions were particularly favorable, about 25 per cent of the area being covered by welldecomposed wood. On Plot 3 there was ample soil moisture in both quadrats of mineral soil. The untrenched quadrat was on level ground at the bottom of a gentle slope, and here the soil "felt" moist throughout the summer. Other conditions on the two quadrats were very similar. The number of spruce seedlings on the two quadrats were 111 and 112 respectively. How. ever, there were a few balsam seedlings on the trenched quadrat. The reason for the greater number of seedlings on the mineral soil quadrats of Plots 7 and 12 than on the trenched quadrats is not clear. Undoubtedly some of the variation in the number of seedlings on the different areas is due to an unequal seed supply.

Although trenching, by eliminating root competition of the surrounding trees, greatly increased the amount of soil moisture and available nutrients within the trenched area, as shown by the much denser vegetation on the trenched as compared with the untrenched quadrats, there was very little difference in seedling development and mortality. Under the mature stand of spruce and balsam there was usually sufficient soil moisture in exposed mineral soil for seedling growth, although under some conditions, such as on steep southern slopes, soil moisture probably became the controlling factor. However, trenching resulted in much denser herbaceous growth which competed successfully with the young seedlings for water and nutrients, offsetting any advantage which had been gained by eliminating the competition from tree roots.

\section{SUMMARY}

In the mature unevenaged stands of spruce and balsam in the central interior of British Columbia, spruce is the more desirable commercial species and is dominant in the forest, comprising over 60 per cent of the basal area of the stand. The understory, however, contains only 18 per cent spruce, which is a very unsatisfactory condition. The poor regeneration of spruce appears to be due to the layers of moss and herbaceous growth on the forest floor, which prevent the germination of spruce seeds.

A large proportion of the spruce reproduction probably originates on welldecomposed wood. When the mineral soil was exposed on the experimental plots by removing the surface layers of moss and humus, regeneration of spruce was satisfactory. During the three seasons under study, a total of 
13,000 seedlings germinated, of which 64 per cent survived at the end of the third summer.

Trenching of the soil on the plots, in order to remove the competition of tree roots had no appreciable effect on the establishment of seedlings under ordinary conditions, but this operation greatly increased the luxuriance and density of the herbaceous flora.

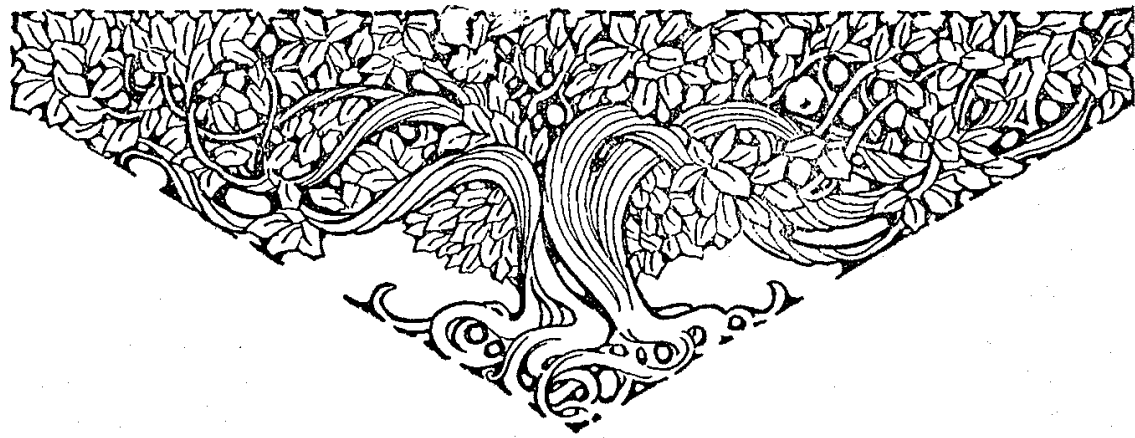

